\title{
ЦІННОСТІ ДИКОЇ ПРИРОДИ В ПОЛІТИЦІ ЄС ТА УКРАЇНИ
}

\section{Перга Тетяна Юріївна}

кандидат історичних наук, старший науковий співробітник, ДУ «Інститут всесвітньої історії НАН України», м. Київ, Україна

ORCID: 0000-0002-8725-3451

pergatatiana@gmail.com
Надіслано:

01.03.2019

Рецензовано:

15.03.2019

Прийнято: 10.04.2019

Метою статті є дослідження впровадження цінностей дикої природи в екологічну політику Європейського Союзу та України. Методологія дослідження базується на порівняльному аналізі діяльності ЄС та України з охорони дикої природи. У результаті дослідження з'ясовано сутність термінів «дика природа» та «цінність дикої природи». Виявлено матеріальну і нематеріальну цінність дикої природи, яка на даний час $\epsilon$ найбільш затребуваною в ЄС. Розглянуто діяльність Європейського Союзу і державчленів ЄС з розвитку законодавчих і стратегічних засад охорони дикої природи. 3'ясовано особливість європейської моделі охорони дикої природи, яка полягає у формуванні стратегічних напрямів, що розвиваються державами-членами ЄС відповідно до національної специфіки. Розкрито головні недоліки діяльності з охорони дикої природи в Україні, зокрема відсутність загальноприйнятого і юридично закріпленого визначення дикої природи. Проаналізовано перші кроки на цьому шляху, серед яких прийняття в 2017 р. закону про охорону пралісів та включення до складу українсько-словацько-німецького об'єкта всесвітньої спадщини ЮНЕСКО «Букові праліси Карпат та давні букові ліси Німеччини» 63 ділянки давніх букових лісів з десяти європейських країн, включаючи Україну. Висновки. Євроінтеграційний курс України вимагає від неї не лише адаптації вітчизняного екологічного законодавства до правових норм $€ C$, але і розвитку окремого напряму екологічної політики охорони дикої природи. Розроблено низку рекомендацій щодо головних заходів, що доцільно здійснити в його рамках, серед яких: розробка відповідного термінологічного апарату у царині дикої природи та введення його у вітчизняне законодавство, створення ділянок дикої природи та прийняття принципів управління ними, заснування постійно діючої експертної групи із залученням представників урядових установ і громадянського суспільства, розвиток громадських ініціатив, пропаганда в українському суспільстві цінностей дикої природи. 
Ключові слова: ЄС; Україна; дика природа; біо-різноманіття; екологічна політика, Карпати; праліси.

Perga Tetiana, Candidate of Historical Science, State Institution "Institute of World History of NAS of Ukraine", Kyiv, Ukraine

\section{Values of wildlife in the policy of EU and Ukraine}

The aim of the article is to study the implementation of wildlife values into the environmental policy of European Union and Ukraine. The research methodology is based on a comparative analysis of the activities of the EU and Ukraine in the protection of wildlife. The study has introduced the essence of the terms "wildlife" and "value of wildlife." The material and nonmaterial value of wildlife, which is currently the most demanded in EU, has identified. The activities of European Union and EU member states in the development of legislative and strategic framework for the protection of wildlife has analyzed. The peculiarity of the European model of wildlife conservation is revealed; it is the formation of strategic directions that are being developed by member-states in accordance with the national specifics. The main shortcomings of the wildlife conservation activities in Ukraine, in particular the lack of a generally accepted and legally enforced definition of "wildlife" has been disclosed. Ukraine's first steps on this path has been analyzed. Among them - the adoption in 2017 of the law "On Amendments to Some Legislative Acts of Ukraine on Protection of Forests under the Framework Convention for the Protection and Sustainable Development of the Carpathians"and the inclusion of 63 plots of ancient forests from ten European countries and Ukraine into the Ukrainian-Slovak-German UNESCO World Heritage Site "Virgin Beech Forests of the Carpathians". It has concluded that the European integration course of Ukraine requires not only the adaptation of domestic environmental legislation to the EU legal norms, but also the development of a separate environmental policy direction - the protection of wildlife. A number of recommendations have been developed for the main activities that should be carried out within its framework, in particular: the development of an appropriate concepts concerning wildlife and its introduction into domestic legislation, the creation of wildlife sites and the adoption of principles for managing them, the creation of a permanent expert group involving government institutions and civil society, the development of public initiatives, the promotion in the Ukrainian society the values of the wildlife.

Key words: EU; Ukraine; wildlife; biodiversity; environmental policy; Carpathians; old forests. 
Перга Татьяна Юрьевна, кандидат исторических наук, старший научный сотрудник ГУ «Институт всемирной истории НАН Украины», г. Киев, Украина

\section{Ценности дикой природы в ЕС и Украине}

Целью статьи является исследование внедрения ценностей дикой природы в экологическую политику Европейского Союза и Украины. Методология исследования базируется на сравнительном анализе деятельности ЕС и Украины по охране дикой природы. В результате исследования установлена сущность терминов «дикая природа» и «ценность дикой природы». Выявлена материальная и нематериальная ценность дикой природы, которая в настоящее время является наиболее востребованной в ЕС. Рассмотрена деятельность Европейского Союза и государств-членов ЕС по развитию законодательных и стратегических основ охраны дикой природы. Раскрыта особенность европейской модели охраны дикой природы, которая заключается в формировании стратегических направлений, которые развиваются государствами-членами ЕС в соответствии с национальной спецификой. Раскрыты главные недостатки деятельности по охране дикой природы в Украине, в частности отсутствие общепринятого и юридически закрепленного определения дикой природы. Проанализированы ее первые шаги на этом пути, среди которых принятие в 2017 г. закона об охране древних лесов и включение в состав украинского-словацко-немецкого объекта всемирного наследия ЮНЕСКО «Девственные буковые леса Карпат» 63 участка древних буковых лесов из десяти европейских стран, включая Украину. Выводы. Евроинтеграционный курс Украины требует от нее не только адаптации отечественного экологического законодательства к правовым нормам ЕС, но и развития отдельного направления экологической политики охраны дикой природы. Разработан ряд рекомендаций относительно главных мероприятий, которые целесообразно осуществить в его рамках. В частности, предлагается: разработать соответствующий терминологический аппарат в области дикой природы и ввести его в отечественное законодательство, создать участки дикой природы и принять принципы управления ими, создать постоянно действующую экспертную группу с привлечением представителей правительственных учреждений и гражданского общества, развивать общественные инициативы, пропагандировать в украинском обществе ценности дикой природы.

Ключевые слова: ЕС; Украина; дикая природа; биоразнообразие; экологическая политика; Карпаты; пралесы. 


\section{Вступ}

Становлення і розвиток техногенної цивілізації, яку часто називають західною, супроводжується формуванням системи нових цінностей. При цьому зростає цінність не лише нових знань, технологій та інновацій, а і дикої природи, яка дозволяє відпочити від них i усамітнитись у куточках, які не зазнали змін внаслідок людської діяльності. Тому останніми роками в європейських країнах спостерігається переосмислення ролі дикої природи і зростання інтересу до неї. Вивчення передового досвіду держав-членів ЄС з охорони дикої природи є актуальним для України, яка обрала шлях інтеграції і має не лише адаптувати своє законодавство до європейського, а і сприйняти систему цінностей, які є важливими для жителів цього регіону.

\section{Аналіз останніх досліджень і публікацій}

Сучасні зарубіжні розвідки 3 цієї проблематики мають міждисциплінарний характер, крім того, невпинно збільшується кількість праць, присвячених практичним аспектам охорони дикої природи. Розробки вітчизняних фахівців з охорони дикої природи нечисленні. Варто вказати на низку праць В.Борейко з питань екологічної етики, філософських засад охорони дикої природи, збереження пралісів в Україні (Borejko, 2018). Більш численною є група робіт, які розглядають дику природуз точки зору організації заповідної справи в Україні (Andronov, Varyvoda, Titenko, 2013). Це актуалізує завдання заповнення існуючої наукової прогалини.

\section{Мета статті}

Дослідження впровадження цінностей дикої природи в екологічну політику Європейського Союзу та України. Компаративний аналіз діяльності у цій царині дозволить оцінити головні проблеми на шляху розвитку охорони дикої природи у нашій країні і розробити низку практичних рекомендацій.

\section{Виділення невирішених раніше частин загальної проблеми}

На даний час у вітчизняній науковій термінології відсутній загальноприйнятий підхід до розуміння сутності (а відповідно - і терміну) «дика природа» (дослівний переклад з англійської - «wilderness»). Це свідчить про нерозробленість цієї наукової проблеми та відсутність відповідного напряму екологічної політики.

\section{Виклад основного матеріалу дослідження}

Для виконання поставлених завдань доречно розглянути термінологічний апарат, що буде використано в цій статті. Під терміном «дика природа», зазвичай, розуміють території, які не зазнали змін у процесі людської діяльності, зберегли багато видів флори і фауни та природні ландшафти (The Wilderness Act, 1964). Під цінністю розуміють певні явища або предмети, які мають матеріальне (економічне), соціальне або культурне значення (Kasijan, 2008, p.28). Щодо екологічної цінності, то у сучасному науковому 
дискурсі не існує загальноприйнятого визначення. Досить часто її розглядають як цінність, здатну забезпечити екологічну рівновагу на Землі та компенсувати антропогенне перетворення екосистем (Abolina, Napadysta, Rukhlitska, 2014, p.23). Дика природа $є$ частиною довкілля, тому цінність дикої природи ми розглядаємо як складову системи екологічних цінностей. 3 огляду на те, що екологічній цінності притаманні риси й особливості, властиві будь-якій цінності,на наш погляд, доречно розглядати цінність дикої природи як 3 матеріальної точки зору (економічна вартість, яку можна виміряти) так і 3 нематеріальної, що включає вплив на світосприйняття людини, ï моральні принципи відносно довкілля (Tadaki, Sinner, Chan, 2005). Через цю призму ми маємо намір проаналізувати цінність дикої природи в Європейському Союзі та Україні.

Першою країною в світі, де на початку 1960-х рр. було прийнято законодавство із захисту дикої природи, є Сполучені Штати Америки, хоча ще наприкінці XIX ст. американські філософи обгрунтували неекономічну цінність дикої природи і її важливе естетичне значення для розвитку нації.

У Європейському Союзі інтерес до дикої природи почав розвиватися лише у 1970-х рр. і був пов'язаний з необхідністю зберегти види дикої флори і фауни, які почали катастрофічно зменшуватися. Зокрема, у 1979 р. ЄС ініціював прийняття Конвенції про охорону дикої флори та фауни і природних середовищ існування в Європі, для виконання якої були прийняті Директива зі збереження диких птахів (1979р.) та Директива про збереження природних оселищ існування дикої фауни і флори (1992р.). Під егідою цієї конвенції заснували мережу охоронних ділянок «Натура 2000» та «Смарагдова мережа», які започаткували процес створення територій особливого природоохоронного значення, на яких знаходяться рідкісні види і такі, що перебувають під загрозою зникнення або руйнування.

Однак цілеспрямовану теоретичну i практичну роботу щодо формування політики охорони дикої природи Європейський Союз повів, починаючи з 2009 р. Цього року з ініціативи створеної в 2005 р. неурядової організації «Дика Європа» (Wild Europe) у Європейському парламенті була зроблена доповідь «Дика природа в Європі», на основі якої прийняли однойменну резолюцію. Вона закликала Європейську комісію розробити визначення дикої природи, яке планувалось покласти в основу відповідного законодавства; створити ділянки дикої природи; прийняти принципи захисту, управління, сталого використання, моніторингу та їх фінансування у рамках мережі «Натура 2000»; прийняти стратегію ЄС 3 дикої природи; розширити співпрацю держав-членів 3 місцевими неурядовими організаціями, зацікавленими сторонами та місцевим населенням для розширення розуміння цінності дикої природи і актуалізації цього питання на порядку денному в ЄС 
(Report on Wilderness in Europe, 2008). Цього ж року у Празі з ініціативи Європейської Комісії відбулась перша конференція з дикого життя «Дика природа та великі природні місця проживання». Велику роль у їі проведенні відіграв екс-президент Чехії Вацлав Гавел. На ній розглядалися такі питання: визначення характеру диких територій та їх розташування, визначення їхнього внеску у припинення втрати біо-різноманіття, можливість таких ділянок підтримувати мережу охоронних територій «Натура 2000», розробка рекомендацій щодо поліпшення їх захисту в рамках існуючої правової бази, огляд можливостей для відновлення великих природних ареалів, визначення вартості економічних, соціальних і екологічних вигод «диких» територій. Головним результатом заходу став фінальний документ «Послання з Праги», що містив 24 рекомендації з подальшої діяльності в цій царині (Old Growth Forest Protection Strategy launched...).

Аналіз документів вказує на надзвичайно важливу роль, яку ЄС приділяє розробці термінологічного апарату стосовно дикої природи. Він розглядається як відправна точка для формування необхідних законодавчих актів, стратегічних документів i практичних заходів. На конференції у Празі з ініціативи «Дикої Європи» була створена Робоча група 3 дикого життя, до складу якої увійшли представники 15 країн: Австрії, Канади, Чехії, Англії, Франції, Фінляндії, Франції, Угорщини, Нідерландів, Румунії, Шотландії, Словаччини, Швеції, США та України. Визначення, запропоноване групою у 2013 р., було узгоджено з дефініцією Міжнародного союзу охорони природи і адаптовано до європейських умов. Наразі під дикою природою в ЄС розуміється територія, яка регулюється природними процесами, складається 3 природних середовищ існування і видів, достатніх для ефективного екологічного функціонування природних процесів; $\epsilon$ незміненою або трохи зміненою і не зазнає нав'язливого впливу людини, населених пунктів, інфраструктури або візуальних змін ландшафту (Guidelines on Wilderness in Natura 2000, 2013). Це визначення планується використовувати до 2030 p. Однак вже у процесі наступних обговорень було запропоновано визнати крім економічної цінності територій дикої природи й неекономічну - значення для духовного та культурного розвитку людей. Наразі вже з'явилась низка напрацювань, в яких здійснено спроби обгрунтувати ії цінність для самовдосконалення, натхнення, виховання патріотичних почуттів. Наприклад, В. Борейко вважає, що найважливішими властивостями дикої природи, яка живе за своїми законами, є свобода, автономія і незалежність. На його думку, потрібно цінувати свободу дикої природи як за їі цінність для людей, видів живих істот і екосистем, але і як благо, яке існує саме по собі (Borejko, 2013, p. 47). 
Економічну цінність дикої природи Європейський Союз розглядає у контексті боротьби з втратою біо-різноманіття, активізації соціального та економічного розвитку. Європейські вчені довели, що райони дикої природи є стійкими до тиску, який впливає на зменшення біо-різноманіття, що робить їх важливим інструментом попередження цього процесу. Велике значення для економічного розвитку ЄС має і розвиток багатьох екосистемних послуг, у першу чергу - туризму. Беручи до уваги високу щільність населення в регіоні і порівняно невелику площу ділянок дикої природи (5 \% території) ЄС вважає своїм обов'язком надати доступ до них якомога більшій кількості громадян. Дика природа може забезпечити значні доходи та можливості працевлаштування. Це відбувається у процесі розвитку туризму та рекреаційних, освітніх, соціальних програм, корпоративного навчанням та інших «сервісних» ініціатив, що мають відношення до розвитку сільських територій та міських потреб. Наприклад, Національний парк «Oulanka» у Фінляндії генерує понад 14 млн євро на рік за рахунок прибутків від розвитку екосистемних послуг (Old Growth Forest Protection Strategy launched). Такі економічні вигоди можуть бути особливо значущими у віддалених регіонах, де традиційне землекористування стає все більш нежиттєздатним, що призводить до занепаду сільського господарства. Загалом ЄС виділяє як прямі матеріальні вигоди від охорони дикої природи (доходи від різних видів діяльності, пов'язаних з такими ділянками, включаючи додаткові вигоди від допоміжних видів діяльності; економія коштів, створення робочих місць), так і непрямі. До останніх віднесено: екологічні переваги - пом'якшення повеней (наприклад економія капітальних витрат, поточних витрат та страхових відшкодувань внаслідок відновлення природного середовища у водозбірних зонах та низинних потоках, що зменшують варіабельність стічних вод або забруднення) та соціальні вигоди (покращення здоров'я або його паліативна охорона, наприклад, зменшення робочих днів, втрачених від стресу; більш короткі курси психотерапії унаслідок відвідування місць дикої природи). Тому політика ЄC спрямована на створення охоронних ділянок, які однак $є$ відкритими для відвідування, проте досить жорстко контролюються 3 урахуванням потреби зберегти їх у недоторканому або мало зміненому виді.

Розвиток цього підходу постерігається на низці конференцій, які мали місце в ЄС протягом останніх років. Крім конференції у Празі в 2009 р. дві зустрічі відбулось у Брюсселі. У 2010 р. була прийнята стратегія з відновлення великих екосистем або територій дикої природи, у 2017 р. - винесена на обговорення стратегія із захисту давніх лісів. На окрему увагу заслуговує останній документ, адже власне з ним і було синхронізовано прийнятий цього ж року в Україні закон про охорону пралісів. Ї̈̈ розробку зумовили виклики збереженню пралісів в Європі, зокрема зростання цін на деревину i iї 
використання, реституція земель, фрагментація унаслідок появи нових транспортних шляхів, вплив боротьби 3 короїдами, яка актуалізується внаслідок зміни клімату. Проблема парку Шумава, ділянки дикої природи якого вирішили у 2009 р. перепрофілювати для боротьби з короїдами і в результаті ледь не втратили цінні праліси, продемонструвала уразливість таких територій i необхідність розробки комплексних заходів для їхнього збереження. Запропонований для дискусії документ закладає загальні рамки політики охорони пралісів, визначає низку охоронних заходів, напрями управління такими територіями, нові можливості для довгострокових заходів з охорони і заходів з відновлення пралісів, джерела фінансування (Old Growth Forest Protection Strategy launched). Наразі він перебуває у процесі доопрацювання й очікується, що незабаром буде прийнятий.

32009 р. працює неформальний Форум 2000, організований під час празької конференції Вацлавом Гавелом. У 2014 р. він зібрався у Празі вдруге. У 2009 р. в ЄС також була створена фундація «Pan Parks», яка разом з і «Дикою Європою» ініціювала створення в Європейському парламенті політичного Форуму «Захист дикості в Європі», до завдань якого входить обговорення теоретичних і практичних досягнень у цій царині. За резолюцію щодо його створення проголосувало 538 депутатів, що засвідчило досить високу екологічну свідомість і прагнення розвивати цей напрям екологічної політики на рівні ЄС. Останнім часом у багатьох європейських країнах з'явились неурядові організації та ініціативи, які пропагують цінності дикої природи і природозахисну діяльність.

Особливість європейської моделі охорони дикої природи полягає у формуванні на рівні Європейського Союзу стратегічних напрямів діяльності, які упроваджуються державами-членами з урахуванням особливостей свого розвитку. Наприклад, у відповідності до прийнятого на рівні ЄС визначення дикої природи були розроблені національні закони, які визначають такі території і регламентують їхню діяльність. Керуючись загальними критеріями вони, разом з тим, визначають різний ступінь недоторканості цих ділянок. Наприклад, у деяких країнах (Болгарія, Естонія, Словенія) на територіях дикої природи заборонена будь-яка людська діяльність; нормативні акти інших країн дозволяють обмежену економічну, рекреаційну та освітню діяльність (Латвія). У Фінляндії дозволено оленярство, рибальство та збирання грибів, якщо ці заходи не заважають досягненню основних цілей ділянок дикої природи. Щодо площі таких територій, то деякі європейські країни визначають їх мінімальний розмір (наприклад, у Фінляндії він становить 1000 га), але зазвичай вона законодавчо не визначена.

Паралельно з цим ведеться робота по вдосконаленню управління територіями дикої природи у рамках мережі «Натура 2000». У 2013 р. 
Європейська комісія опублікувала посібник для управління диким життям в мережі «Натура 2000». Це обумовлено тим, що до складу мережі (вона охоплює більше 18 \% наземної території держав-членів ЄC і значну площу морських ділянок) входять як ділянки, що зазнали значних змін у процесі людської діяльності, так і території, які збереглись у відносно непорушеному природному стані. Вважається, що впровадження викладених у ній принципів допоможе забезпечити збереження природних середовищ незруйнованими від розвитку таких традиційних форм втручання людини, як збирання лікарських рослин, розвиток інфраструктури тощо. Ці керівні принципи ЄС втілюють підхід до управління діяльністю зі збереження дикої природи, що базується на центральній ролі природних процесів і зосереджується на цілісності функціонуючої екосистеми, а не на потребах окремих видів або середовищ існування. Водночас цей підхід пропонується використовувати лише у тих випадках, де для цього існує можливість. Документ зібрав приклади найбільш поширених та ефективних заходів, які наразі використовуються європейськими державами для управління такими територіями. Серед них: зонування територій 3 метою поєднання захисту дикої природи та напівприродного характеру і сталого відпочинку (Швеція, Естонія, Греція), забезпечення екологічного зв'язку з прилеглими територіями для підтримки міграцій природних видів (Німеччина, Австрія, Болгарія), відновлення модифікованих ареалів (Австрія, Німеччина), моніторинг та надання можливостей для дослідницької діяльності (Польща, Італія, Словакія), запобігання лісовим пожежам шляхом створення буферних зон з ділянок дикої природи (Португалія, Італія), надання навчальних і перекладацьких послуг для відвідувачів, шкіл і місцевих громад (Швеція, Фінляндія), створення служби рейнджерів (Італія) (Guidelines on Wildernessin Natura 2000, 2013). Отже у Європейському Союзі розвивається як теоретична, так і практична діяльність з охорони дикої природи, яка усе більше набуває комплексний характер.

Як і європейські країни, Україна вже не одне десятиріччя розвиває діяльність зі створення охоронюваних державою територій, що $\epsilon$ не лише вимогою сьогодення, а і важливим напрямом екологічної політики. Однак охорона дикої природи $є$ новим напрямом, який тільки почав формуватися. На даний час ця ідея реалізується в Україні через охорону лісів, зокрема пралісів. Так як цей вид лісів не зазнав безпосереднього впливу діяльності людини упроцесі свого розвитку, то він має важливу природоохоронну, наукову та етичну цінність. Праліси є місцем оселення значної кількості видів флори і фауни, занесених до Червоної книги України, зберегти які можливо лише завдяки режиму заповідності. Головною загрозою їх існуванню є різні види людської діяльності, зокрема санітарні та інші види рубок, будівництво 
транспортних магістралей, туризм, випас худоби, пожежі, заготівля лікарської сировини, які позбавляють праліси ключових критеріїв ідентифікації.

Про охорону пралісів йдеться в деяких міжнародних документах Рамковій конвенції із захисту та сталого розвитку Карпат (п. 5 ст. 7) (Ramkova konventsiia pro okhoronu ta stalyi rozvytok Karpat) та Всеєвропейській стратегії збереження біологічного та ландшафтного різноманіття (п. 9.1. та 9.2.) (The EU 2020 Biodiversity Strategy, 2011). Праліси, що входять до складу Карпатського біосферного заповідника та Ужанського національного парку, з 2007 та 2011 рр. включені до природної спадщини ЮНЕСКО «Букові праліси Карпат та старі букові ліси Німеччини».

У 2017 р. Україна здійснила перший вагомий захід з охорони дикої природи - прийняла Закон про внесення змін до деяких законодавчо актів України відносно охорони пралісів згідно до Рамкової конвенції про охорону та сталий розвиток Карпат (Zakon Ukrainy «Pro vnesennia zmin do deiakykh zakonodavchykh aktiv Ukrainy vidnosno okhorony pralisiv zghidno do Ramkovoi konventsii pro okhoronu ta stalyi rozvytok Karpat»). Він законодавчо закріпив охорону усіх українських пралісів Карпатських гір, площа яких сьогодні складає близько 70 тис. га, та пралісів, дещо змінених унаслідок людської діяльності (їх віднесено до категорії квазі пралісів і природних лісів). Прийняття цього законопроекту засвідчує прагнення України наблизити своє законодавство до європейського, зокрема закріпити в ньому природні цінності європейського значення. Цей документ засвідчує певне прагнення синхронізувати охорону пралісів в Україні 3 аналогічною діяльністю Європейського Союзу. Євроінтеграційний поступ України сприяє приведенню її законодавчого поля у відповідність до вимог низки важливих європейських природоохоронних документів - Бернської конвенції про охорону дикої флори та фауни i природних середовищ існування в Європі, Рамкової конвенції про охорону та сталий розвиток Карпат, Протоколу про стале управління лісами до цієї конвенції, Всеєвропейської стратегії збереження біологічного і ландшафтного різноманіття тощо.

Крім того, Україна взяла участь у європейській ініціативі зі створення спільних заповідних територій. Зокрема 13 липня 2017 р. на сесії комітету ЮНЕСКО у Кракові було прийнято рішення включити до складу українськословацько-німецького об'єкта всесвітньої спадщини ЮНЕСКО «Букові праліси Карпат та давні букові ліси Німеччини» 63 ділянки давніх букових лісів здесяти європейських країн. Разом з такими ділянками, розташованими в Албанії, Австрії, Бельгії, Болгарії, Хорватії, Італії, Румунії, Словенії, Іспанії до об’єктів світового значення включили й українські ділянки, що перебувають під охороною в національних природних парках «Синевир», «Зачарований край», «Подільські Товтри» та природних заповідниках «Горгани» і «Розточчя» 
(Ostap Semerak: «Bukovi lisy, yaki nalezhat do vsesvitnoi spadshchyny YuNESKO, stanut chastynoiu natsparku»).

У 2018 р. експертна група з підготовки номінаційного досьє об'єкта Всесвітньої спадщини ЮНЕСКО «Букові праліси і давні ліси Карпат та інших регіонів Європи», яка зібралась на чергову зустріч в Австрії, прийняла рішення про спільне управління об'єктами природної спадщини, розташованими на території 12 країн. Цим було зроблено ще один крок на шляху збереження букових лісів, які відіграють важливу роль у лісових екосистемах усієї Європи, включаючи Україну (Krainy, na terytoriiakh yakykh roztashovani bukovi pralisy YuNESKO, domovylysia pro spilne upravlinnia terytoriiamy). Він продемонстрував прагнення України не лише розвивати діяльність 3 охорони букових лісів, які обіймають важливе місце у збереженні лісових екосистем на теренах Європи, а й узгодити її з політикою сусідніх країн.

\section{Висновки з даного дослідження і перспективи}

Маємо констатувати, що в Україні відбувається процес поступового формування системи європейських екологічних цінностей. Зокрема. зростає розуміння цінності дикої природи, на що вказує прийняття перших законодавчих актів та входження представників України до низки міжнародних установ, які працюють в галузі охорони дикої природи. Однак для ефективного розвитку подальшої діяльності в цьому напрямі нагальною $є$ необхідність розробити відповідний термінологічний апарат та низку нових правових норм, які створять механізми віднесення охоронних територій до цієї категорії;прийняти принципи управління ними; створити постійно діючу експертну групу з дикої природи із залученням представників урядових установ і громадянського суспільства; розвивати громадські ініціативи та пропагувати цінності дикої природи в українському суспільстві. Крім цього, на наш погляд, актуальним завданням $\epsilon$ розробка і прийняття стратегії 3 охорони пралісів, адже одного закону для ефективної діяльності в цій царині недостатньо. Вона має включати не лише керівні принципи і заходи щодо управління такими територіями, а й заходи стосовно попередження їх знищення та механізми залучення до цієї діяльності представників бізнесу, громадянського суспільства, місцевих громад та пересічних громадян. Доцільно скористатись і передовим досвідом ЄС щодо створення реєстру дикої природи, який об'єднає всі території, віднесені до цієї групи. Не менш важливим є впровадження у практику управління територіями, включеними до мережі «Натура 2000» і «Смарагдова мережа» принципів охорони дикої природи, розроблених у Європейському Союзі. Потребою сьогодення $\epsilon$ навчання українських фахівців, які працюють у цій сфері, організація спільних наукових заходів, наприклад, конференцій, семінарів, дискусій державних службовців, експертів та представників громадянського суспільства. Таким чином, на даний 
час перед Україною стоїть завдання розробки такого окремого напряму екологічної політики, як охорона дикої природи, що є перспективою подальших наукових розробок.

\section{References:}

1. A Working Definition of European Wilderness and Wild Areas. (2015). Europark Federation, [online]. Available at: https://www.europarc.org/wpcontent/uploads/2015/05/a-working-definition-of-european-wilderness-and-wildareas.pdf [Accessed 18 February 2019].

2. Abolina, T. H., Napadysta, V. H., Rukhlitska, O. D. (2014). Prykladna etyka [Applied ethics]. Kyiv: Tsentr uchbovoi literatury.

3. Andronov, V. A., Varyvoda, E. O., Titenko, H. V. (2013). Zapovidna sprava [Activities on reservation]. Kharkiv: National University of Civil Defense of Ukraine.

4. Borejko, V. E. (2018). Ohrana dikoj prirodu v Ukraine i mire [Wildlife protection in Ukraine and the world]. Kiev: Logos.

5. Guidelines on Wilderness in Natura 2000 (2013). Belgium: European Union.

6. Kasijan, V .I. (2008). Filosofiia [Philosophy]. Kyiv: Znannia.

7. Krainy, na terytoriiakh yakykh roztashovani bukovi pralisy YuNESKO, domovylysia pro spilne upravlinnia terytoriiamy [The countries in which there are beech forests YUNESKO agreed on joint management of territories]. Ministerstvo ekolohii ta pryrodnykh resursiv Ukrainy [Ministry of Ecology and Natural Resources of Ukraine], [online]. Available at: https://menr.gov.ua/news/31766.htm [Accessed 17 February 2019].

8. Old Growth Forest Protection Strategy launched. Wild Europe, [online]. Available at: https://www.wildeurope.org/[Accessed 27 February 2019].

9. Ostap Semerak: «Bukovi lisy, yaki nalezhat do vsesvitnoi spadshchyny YuNESKO, stanut chastynoiu natsparku» [Ostap Semerak: "Beech forests belonging to the UNESCO World Heritage Area will be part of the National Park]. Ministerstvo ekolohii ta pryrodnykh resursiv Ukrainy [Ministry of Ecology and Natural Resources of Ukraine], [online]. Available at: https://menr.gov.ua/search/?s=\%D0\%B1\%D1\%83\%D0\%BA\%D0\%BE\%D0\%B2\%D 1\%96+\%D0\%BB\%D1\%96\%D1\%81\%D0\%B8 [Accessed 19 February 2019].

10. Ramkova konventsiia pro okhoronu ta stalyi rozvytok Karpat [Framework convention on the protection of the Carpathians Verkhovna Rada Ukrainy, [online]. Available at: https://zakon.rada.gov.ua/laws/show/998_164 [Accessed 28 February 2019].

11. Report on Wilderness in Europe. (2008). European Parliament, [online]. Available at: http://www.europarl.europa.eu/sides/getDoc.do?pubRef=//EP//TEXT+REPORT+A6-2008-0478+0+DOC+XML+V0//EN [Accessed 19 February 2019]. 
12. Tadaki, M., Sinner, J., Chan, K. M. (2005). 'Making sense of environmental values: a typology of concepts'. Ecology and Society. no. 22 (1), [online]. Available at: https://www.researchgate.net/publication/228624754_Environmental_Values [Accessed 19 February 2019].

13. The EU 2020 Biodiversity Strategy. (2011). Belgium: European Union.

14. The Wilderness Act of 1964. (1964). Wilderness connect, [online]. Available at: https://www.wilderness.net/nwps/legisac t[Accessed 11 February 2019].

15. Zakon Ukrainy «Pro vnesennia zmin do deiakykh zakonodavchykh aktiv Ukrainy vidnosno okhorony pralisiv zghidno do Ramkovoi konventsii pro okhoronu ta stalyi rozvytok Karpat» :stanom na 2017, veresen 03 [Law of Ukraine "On Amendments to Certain Legislative Acts of Ukraine Concerning the Protection of Virgin forests in accordance with the Framework Convention for the Protection and Sustainable Development of the Carpathians", dated September 03 2017]. Verkhovna Rada Ukrainy, [online]. Available at: https://zakon.rada.gov.ua/laws/show/2063-19 [Accessed 19 February 2019].

(C) Перга Т. Ю., 2019 